\title{
Interview with Momoyo Kaijima of Atelier Bow-Wow
}

\author{
Sarosh Mulla and Patrick Loo
}

Momoyo Kaijima was born in Tokyo in 1969. She founded the Tokyo-based firm, Atelier Bow-Wow, with Yoshiharu Tsukamoto (born 1965, Kanagawa) in 1992. The pair's interests range from urban research to architectural design and public artwork. Their research works are epitomised by the publications Pet Architecture Guidebook and Made in Tokyo. While on the one hand the practice has designed over 20 detached houses such as Gae House (2003) and House \& Atelier BowWow (2005), recent projects such as Hanamidori Cultural Centre in Tokyo (2005) mark an expansion towards a larger scale. Their artwork has been exhibited across the world at Biennales in Korea, China, Japan, Italy and Brazil.

Momoyo Kaijima visited New Zealand as The University of Auckland School of Architecture and Planning International Architect in Residence for 2010. Sarosh Mulla and Patrick Loo interviewed her at the Auckland Regional Council offices on 6 August 2010.
Since forming Atelier Bow-Wow in 1992, Yoshiharu Tsukamoto and Momoyo Kaijima have been responsible for some of the quirkiest and most subtly nuanced work produced by their still-young generation of architects. Their seemingly light-hearted name masks an extremely insightful research-based practice; this is not to say they are paper architects. Their projects range in scale and are defined by spatial inventiveness rather than aesthetic brand. They have gained notoriety for shoehorning complex buildings into tightly-packed urban neighborhoods. This notoriety has developed steadily into a loyal following, and as Japanese architecture becomes more and more the focus of the international discourse, Atelier Bow-Wow seems set to become a central figure in the development of architecture globally.

The Atelier Bow-Wow pair is prolific. They have published and built an enormous amount in their relatively short careers thus far, and the quantity of this work is matched by its quality. The work has its roots in effective, practical research, and is aided by the laboratory system of Japanese architecture schools; each student joins the laboratory of a particular professor, with the lab often taking on larger or ongoing projects as a group. Kaijima's own laboratory is based at Tsukuba University and is a mixture of undergraduate, masters and doctoral students. In her own words, "the university provides a good framework by which to be responsible to the public", and this belief can be seen throughout Atelier Bow-Wow's academic and practice-based pursuits. For Kaijima, her work at the university allows dedication to design ideas, meaning that architecture does not have to submit to being "business more than research". For Atelier Bow-Wow, design at the most fundamental level needs to be "for our enjoyment, for our pleasure", otherwise, in their eyes, "quality will go down". When asked how they manage to squeeze in time for both practice and research, Kaijima points out that their work time is "always continuous. When the two types of work are similar, you can get them to work together a little bit easier."

Both Tsukamoto and Kaijima have taught at some of the most progressive institutions in the world, including the Harvard Graduate School of Design and the Eidgenössische Technische Hochschule(ETH) in Zurich. These schools are known for pursuing new approaches to design, and Atelier Bow-Wow's contribution is apparent in their research into what might be described as "evolutionary urbanism", that is, the way the city makes and remakes itself following its own laws of selection. Their investigations into tiny "pet architecture" showed how in-between spaces get adopted and developed in Tokyo, often resulting in quirky buildings that wouldn't occur on green field sites, or even in less densely populated cities. Following these investigations the practice also presented their own speculative designs for "pet architectures". Of course, understanding that 
no space in the city need be wasted will inevitably translate into their domestic designs; within Atelier Bow-Wow's houses, every space is exploited. There are lessons here for our own cities, as we learn to deal with urban densification. Atelier Bow-Wow's work shows that even if the quarter-acre dream is now slipping beyond the means of most, we need not view being squeezed into the city as a necessarily bad thing - it can force an exciting re-imagining of what constitutes domestic space.

Atelier Bow-Wow's latest publication is Behaviorology (Tsukamoto \& Kaijima 2010). The meaning of the book's title is defined on its cover, and gives an indisputable sense of direction for the work inside. Behaviorology, the book cover says, is a subjective field of interpretation that focuses on the study of "functional relations between behavior and its independent variables in the behavior-determining environment". Anthropologists and psychologists might be entirely comfortable with such a definition, but within the field of architecture it represents a distinctly provocative change of direction. Behaviorology stands to completely reverse the ubiquitous uniformity of style, colour, shape and volume that characterised the International Style as well as the reticent architecture produced in the decades following the demise of post-modernism. It sets the scene for pluralistic solutions and binds program into a driving role in the design process. A way of living can be designed in parallel to the architecture, rather than simply resulting from it. Atelier Bow-Wow refer to this as "behavior-engineering".

In this respect, Atelier Bow-Wow's projects are humanist. They study the role of humans within architecture in a way that goes beyond the empirical analysis of data employed as a methodology by offices such as OMA or MVRDV. Atelier Bow-Wow embraces more the subjective facets of the brief, such as the client's dreams, personal goals, and even their desire to make their pets happy. While such subjective issues could prove slippery, it seems that with each brief the pair are able to move beyond any obvious responses and to deliver instead a novel rethinking of program and occupation.

While at first glance some Atelier Bow-Wow projects could be written off as pure formalism, each is anchored by a genuine consideration of the inhabitation of the interior. The resulting spatial complexity, particularly in their residential projects, results in a new way of living. The House Tower in Tokyo (2006), which is based on their observations of the way land in Japan is subdivided over the generations, exemplifies this approach. Producing a family home with a total floor area of $65.28 \mathrm{sqm}$ on a $42.29 \mathrm{sqm}$ site while only creating a building footprint of 18.44sqm takes skill. It takes even greater skill to produce such a building with moments of genuine spatial delight and generosity. Living spaces flow vertically into each other, creating elegant volumes and articulating the program across the various split-levels. The idea is materialised in concrete and glass, distilled to the point where the form of the house represents the program, the history of the city, and the social processes that have made this type of housing necessary. The finishing of this project is of the usual high Japanese standard, but it is its reconsideration of high-density housing typologies that is particularly interesting. Kaijima explained how this vertically works in her own house (Fig. 1): "In the case of House and Atelier Bow-Wow, we had a twelve meter difference in height 
Fig. 1: House and Atelier Bow-Wow, Shinjuku, Tokyo (2005)

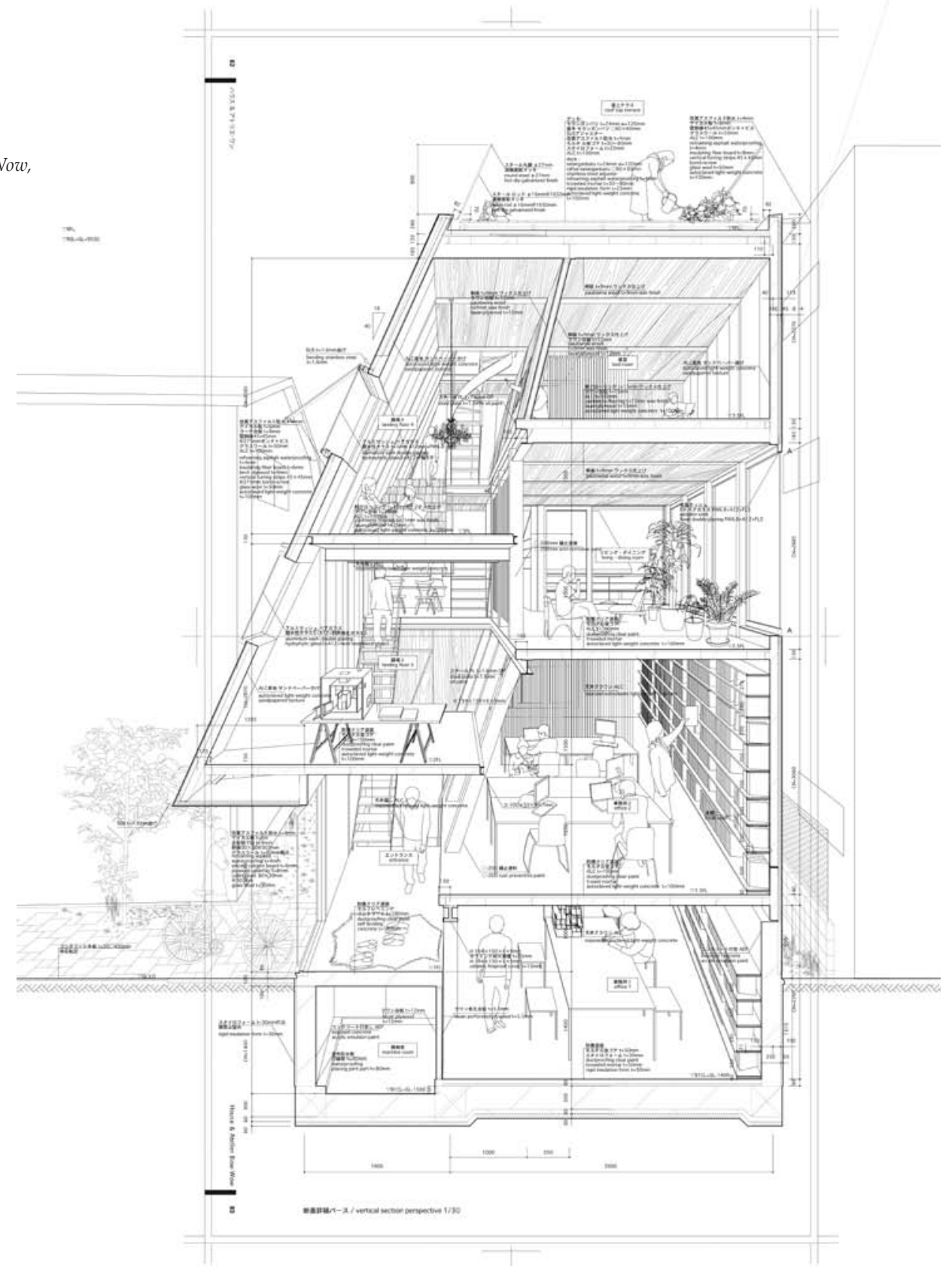

from bottom to top ... I tried to create connectivity, but in person the experience of this is more one of this corner, that corner, another corner. That means the contact you feel is not so strong: you are aware that other people are there, but it is not so disturbing. This vertical type of connection is very interesting."

The practice conveys their concern with occupation through their drawings by adding a perspectival projection to plans and sections. These drawings show the occupants sleeping, eating and generally living in the space. These drawings are not simply ink sketches showing a stylised image of the volume, but are highly detailed construction drawings that also communicate texture, light and other tactile elements rarely included in CAD drawings. Another feature of these drawings is that they show an understanding of the building in relation to the client. Atelier Bow-Wow's architecture does not imagine an idealistic living environment littered with objects cut from magazines; they are concerned with producing a direct response to client needs that doesn't rely on creating a neutral, 'flexible', and gallery-like backdrop. Why should the occupant have to buy new furniture? 
To facilitate the successful delivery of such spaces, Atelier Bow-Wow conducts discussions with their clients about their previous spatial experiences - what their previous homes were like, and what they did and didn't enjoy about their workspaces. These discussions lead to consideration of how the designs of spaces might affect the behavior of the occupants, resulting in a re-evaluation of the way in which people conduct their lives. This raises an interesting point about the work of Atelier Bow-Wow: its quality is not linked to its context or scale. The office also has no defined aesthetic style. Their output is defined instead by a way of working that focuses on the uniqueness of their clients. "Every client is looking for something different. That's why our designs are so different for each project. We always try to find something new in the surrounding area. Our method is based on research, but we always adapt and change. The objective is the same but the approach is different."

When asked whether or not Atelier Bow-Wow gets to choose its clients, Kaijima answers, "Basically we don't choose. We give some kind of conditions based on time or budget and so on. If the project doesn't fit the conditions then it's very simple, we don't do it." Kaijima does point out that most of their clients are architecturally knowledgeable, and as they are often also from creative fields they are not strangers to the creative process. This awareness allows the pair to start the design process one step ahead, which in turn allows them to push the client and their brief further within the time and budget provided. Clients who have made a deliberate and educated decision to engage a practice like Atelier Bow-Wow are expecting their brief to generate a challenging response.

Atelier Bow-Wow's practice is based on discussion, and on the idea that what is around us is worth interrogating. It also assumes that architecture can be both a lens for viewing the society in which we live, as well as a mechanism for changing that society. "I like to talk to people through architecture issues. The subject of the discussion might be some other issue, but we always try to look for its relationship to architecture and society or culture. Architecture always helps me to understand what's happening in each different city or society."

\section{References:}

Tsukamoto, Y. \& Kajima, M. (2010). Behaviorology. New York (NY): Rizzoli. 